\title{
Aripiprazole-Induced Pulmonary Toxicity in a Patient with Obsessive-Compulsive Disorder
}

\author{
Obsesif -Kompulsif Bozukluk Tanılı Hastada Aripiprazol ilişsili Akciğer \\ Toksitesi
}

Fatma Selen Ala', Mustafa Emre Duygulu², Nurhan Köksal' ${ }^{1}$ Tibel Tuna'

\section{Abstract}

A 33-year-old male patient with a diagnosis of obsessive-compulsive disorder applied to the emergency department with fever, cough, sputum and increasing shortness of breath. A physical examination revealed the patient to be dyspneic and orthopneic. Bilateral rales were present in middle and basal lung areas. Oxygen saturation in room air was 84\%. Diffuse parenchymal infiltration and consolidation areas were noted in a posteroanterior chest X-ray and a thorax computerized tomography. The patient's history revealed that the patient used a CPAP machine due to obstructive sleep apnea syndrome and aripiprazole, related to his obsessive-compulsive disorder. The patient was hospitalized in the intensive care unit with a preliminary diagnosis of pneumonia and treated with ceftriaxone $2 \mathrm{gr} /$ day, clarithromycin $2 \times 500 \mathrm{mg}$ and oseltamivir $2 \times 75 \mathrm{mg}$. Blood and sputum cultures, viral markers and procalcitonin were negative, and so methylprednisolone $40 \mathrm{mg} /$ day was started. The patient's clinical condition improved rapidly after treatment with steroids, and he was discharged on the 8th day after admission, with recommendations for ambulatory care. It was learnt that aripiprazole had been added to his treatment for obsessive-compulsive disorder 1 month earlier, and that his complaints had started and gradually intensified 20 days after this change in medication. The patient's clinical picture was assessed as lung toxicity caused by aripiprazole.

Key words: Lung toxicity, aripipirazole, drug lung.

\section{Özet}

Obsesif-kompulsif bozukluk tanısı olan 33 yaşında erkek hasta acil servise, ateş, öksürük, balgam ve giderek artan nefes darlığı ile başvurdu. Fizik muayenesinde dispneik ve ortopneik idi. Dinlemekle bilateral akciğer orta ve basallerde ralleri mevcuttu. Oda havasında oksijen saturasyonu \%84 idi. Direkt akciğer grafisi ve toraks bilgisayarlı tomografisinde her iki akciğerde yaygın parankimal infiltrasyon ve konsolidasyon alanları mevcuttu. Hikayesinde obstrüktif uyku apne sendromu için CPAP ve obsessif -kompulsif bozukluk nedeniyle de aripipirazol kullandığı öğrenildi. Hasta pnömoni ön tanısıyla yoğun bakıma yatırılarak seftriakson 2 gr/gün, klaritromisin 2×500 mg ve oseltamivir 2x75 mg tedavisi başlandı. Yapılan kan ve balgam kültüründe üreme olmadı. Viral markırları ve procalsitonin negatif geldi. Bunun üzerine metil prednisolon $40 \mathrm{mg} / \mathrm{gün}$ başlandı. Steroid tedavisinden sonra kliniği hızla düzeldi. Yatışının 8. günü hasta ayaktan takip edilmek üzere önerilerle taburcu edildi. Obsessif- kompulsif bozukluk için tedavisine 1 ay önce aripipirazol eklenmiş ve şikayetleri bu ilaç değişikliğinden 20 gün sonra başlayarak giderek şiddetlenmiş olduğu öğrenildi. Bu nedenle klinik tablo aripiprazole bağlı akciğer toksisitesi olarak değerlendirildi.

Anahtar Sözcükler: Akciğer toksisitesi, aripiprazol, illaç akciğeri.
'Departmant of Chest Disease, On Dokuz Mayıs Univercity Medicine Faculty, Samsun, Turkey

${ }^{2}$ Departmant of İnternal Medicine, On Dokuz Mayıs Univercity Medicine Faculty, Samsun, Turkey
'On Dokuz Mayıs Üniversitesi Tıp Fakültesi, Göğüs Hastalıkları Anabilim Dalı, Samsun

${ }^{2}$ On Dokuz Mayıs Üniversitesi Tıp Fakültesi, İç Hastalıkları Anabilim Dalı,Samsun

Submitted (Başvuru tarihi): 21 .02.2020 Accepted (Kabul tarihi): 28.08.2020

Correspondence (iletişim): Fatma Selen Ala, Departmant of Chest Disease, On Dokuz Mayıs Univercity Medicine Faculty, Samsun, Turkey

e-mail: selennala@gmail.com 
Lung diseases associated with drugs are common iatrogenic diseases. Drug-induced lung damage leads to acute and chronic lung parenchymal damage. Recognizing drug-related lung diseases can be difficult, as histopathological findings are not specific and have similar features to diffuse lung diseases that develop due to other reasons. For a diagnosis of drug-induced diffuse lung disease, exposure to the drug, and histological evidence of lung damage and other causes must be excluded.

\section{CASE}

A 33-year-old male patient with a diagnosis of obsessivecompulsive disorder applied to the emergency unit with fever, cough, sputum and increasing shortness of breath that were learnt to have started approximately 10 days earlier, and to have increased gradually. When the complaints had first started, he applied to his family doctor and was treated with paracetamol and cephuroxime - the patient had followed the treatment, but had not benefitted. Upon examination at the emergency unit, the general condition of the patient was moderate-bad, tachypneic and orthopneic. A physical examination revealed blood pressure of 130/80 $\mathrm{mmHg}$; pulse, 118/min; respiration, $22 / \mathrm{min}$; and body temperature, $36.8^{\circ} \mathrm{C}$. The mucosa was observed to be slightly cyanotic, and diffuse rales were heard in the bilateral basal lung fields. Without oxygen treatment, oxygen saturation was determined to be $84 \%$ $\left(\mathrm{FiO}_{2} 21 \%\right)$ upon pulse oxymetry. A postero-anterior chest $X$-ray revealed diffuse parenchymal infiltration and consolidation areas, which were more significant in mid and lower zones of both lungs (Figure 1). A thoracic computed tomography without contrast (CT) revealed diffuse alveolar consolidation areas that were more dominant in the peripheral regions of both lungs (Figure 2). The laboratory values upon emergency unit admission were as follows: hemoglobin, $13.4 \mathrm{gr} / \mathrm{dl}$; white blood cell count, 7600 uL; eosinophil count, 510 /uL (\%6.8); thrombocyte, 357,000 /uL; arterial blood gases, $\mathrm{pH}: 7.44 ; \mathrm{pO} 2,50$ $\mathrm{mmHg} ; \mathrm{pCO}_{2}, 41 \mathrm{mmHg}$; and $\mathrm{HCO}_{3}, 26 \mathrm{mmol} / \mathrm{L}$. All parameters other than high creatinine in blood biochemistry were normal (creatinine, $1.61 \mathrm{mg} / \mathrm{dl}$ ).

Due to the need for advanced respiratory support, the patient was admitted to the ICU with a preliminary diagnosis of pneumonia. Treatment was started with oxygen 4-5 It/min, CPAP $10 \mathrm{cmH}_{2} \mathrm{O}$, ceftriaxone $2 \mathrm{gr} /$ day and oseltamivir $2 \times 75 \mathrm{mg}$.

Sputum and blood cultures were negative; the procalcitonin value was $0.349 \mathrm{ug} / \mathrm{l}$, which was within normal limits. In the serologic tests requested due to vasculitis suspicion, antinuclear antibody (ANA), antimitocondrial antibody (AMA), Anti jo-1, Anti ssA and ssB, cytoplasmic anti-neutrophilic antibody (c-ANCA) and peri-nuclear anti-neutrophilic antibody ( $\mathrm{p}-\mathrm{ANCA}$ ) were negative. No pathologic findings were noted in an echocardiography. When the patient history was inquired, it was learnt that he was using a CPAP device at home due to obstructive sleep apnea, and that he had been followed up for more than one year due to obsessive compulsive disorder, being on medication that had been changed within the last 2 months. There was no other medication, allergen exposure, asthma history, animal contact, travel history or smoking history. The patient's shortness breath had started approximately 20 days after starting aripiprazole treatment (Abilify ${ }^{\circledR} 5 \mathrm{mg} /$ day) and had then gradually intensified, with a significant increase seen in the last 5 days. Accordingly, the Aripiprazole treatment was stopped and thereafter, $1 \mathrm{mg} / \mathrm{kg} /$ day methyl prednisolone was started. On the second day of methyl prednisolone treatment, symptoms and oxygen saturation started to recover. After three days in the ICU, the patient was transferred to the service, and eight days after presenting to the emergency unit, the patient was discharged with a $24 \mathrm{mg} /$ day methyl prednisolone oral and dose reduction plan. The patient's medication was replaced with citalopram and haloperidol treatment after obtaining the opinion of the psychiatry department. The lesions saw almost complete remission on lung imaging and thorax $\mathrm{CT}$ performed in the first month (Figure 3 and 4). Due to the observation of radiologic improvement, the methyl prednisolone treatment dose was reduced and then stopped.

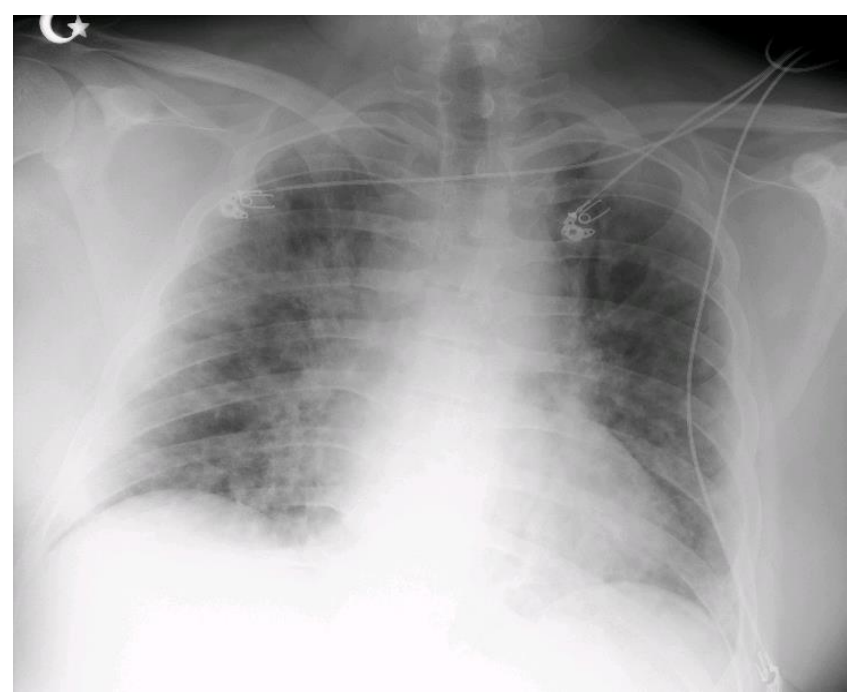

Figure 1: Postero-anterior (PA) chest radiography: Diffuse parenchymal infiltration and consolidation areas in both lungs that are more significant in the middle and lower zones 


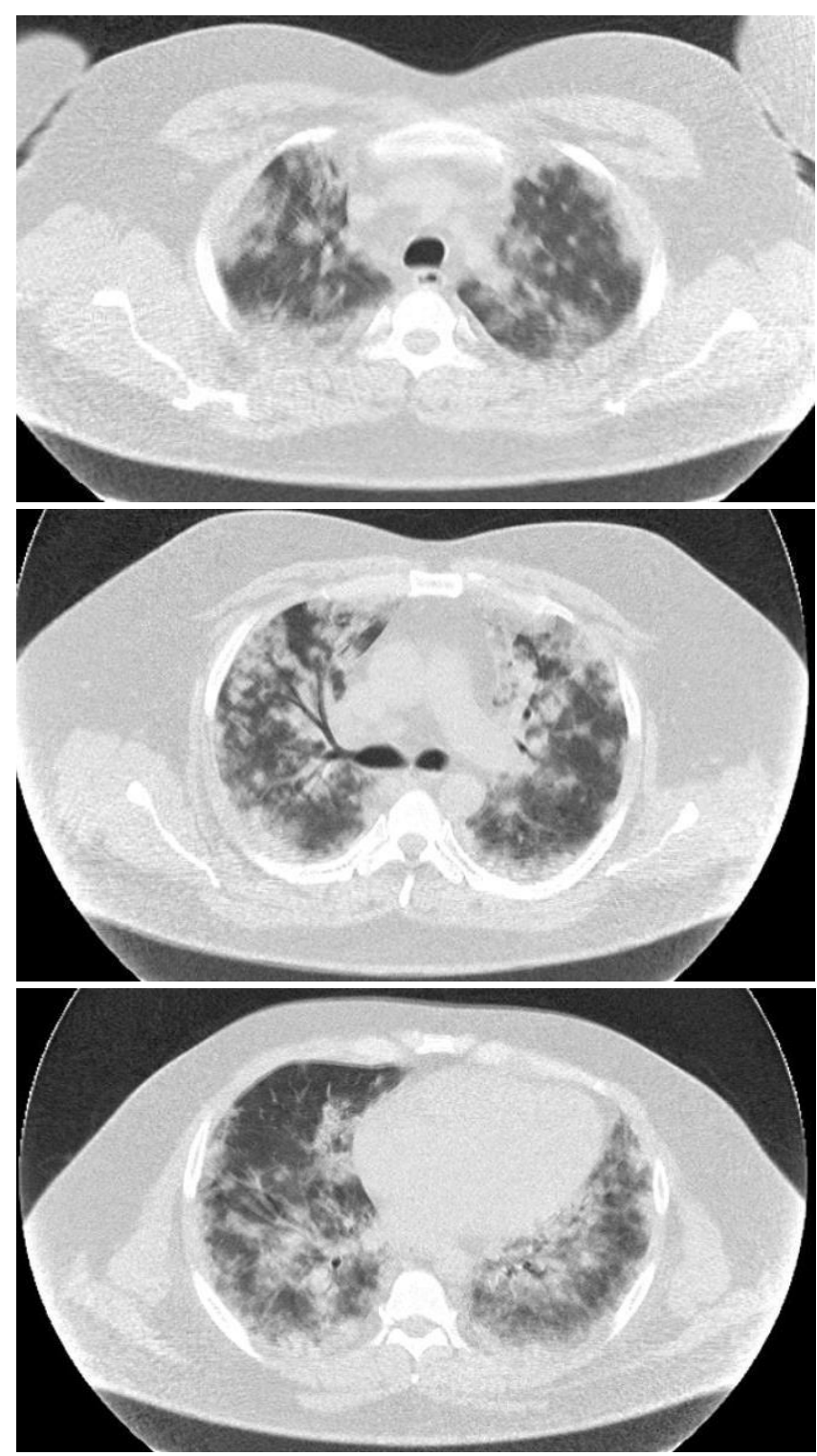

Figure 2: Thorax computerized tomography (CT) without contrast: alveolar consolidation areas in both lungs that are more dominant in peripheral areas

\section{DISCUSSION}

Due to their large contact area, the lungs are a potential target for toxic materials through both inhalation and hemathogenic paths. Medications can be included among such toxic materials, as they may cause specific respiratory tract reactions. It is well known that there are more than 380 pharmaceutical agents that can cause medication-induced respiratory system diseases (1).

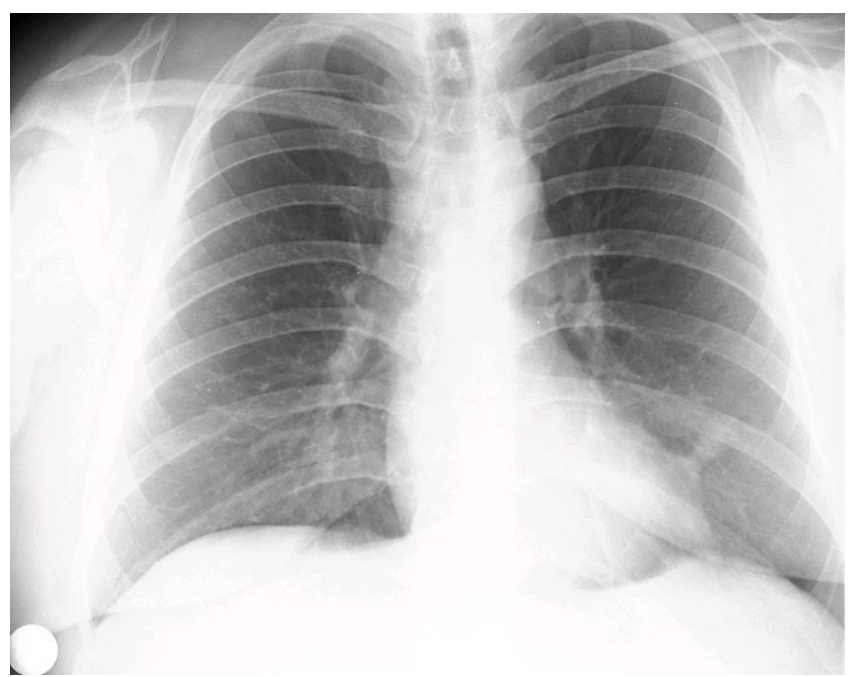

Figure 3: PA chest radiograph of the patient taken in the first month: full remission in consolidated areas
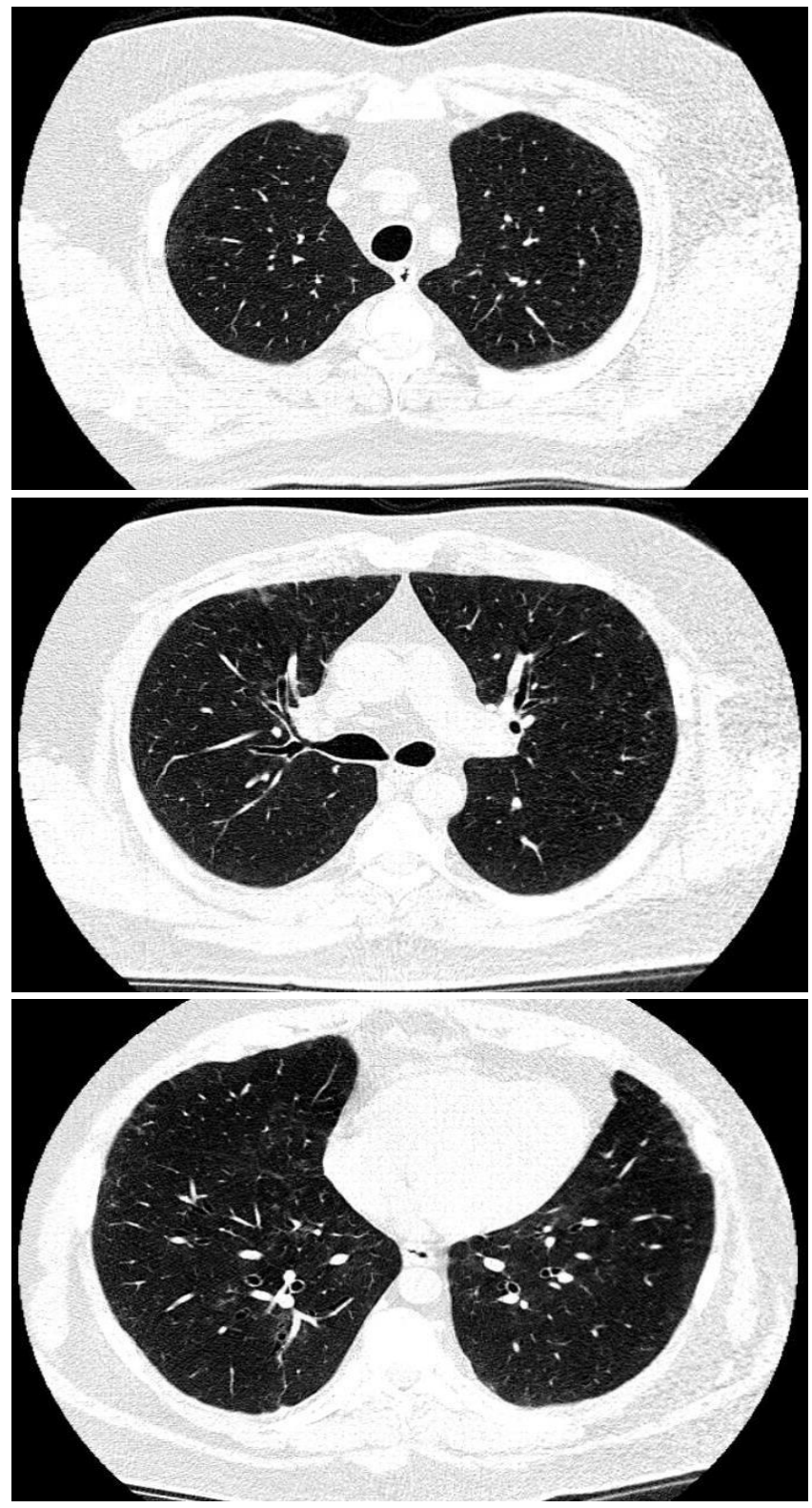

Figure 4: Thorax CT of the patient taken in the first month: Normal lung parenchyma 
The most common form of drug-induced lung toxicity is drug-related interstitial lung disease (DRILD). DRILD can be observed in almost all histopathologic types, such as interstitial pneumonia, hypersensitivity pneumonia (HP), diffuse alveolar damage (DAD), non-specific interstitial pneumonia (NSIP), eosinophilic pneumonia, organizing pneumonia, alveolar hemorrhage and granulomatous pneumonia (1). The use of oral and parenteral medication can cause interstitial lung disease more frequently than inhaler, intrathecal or local use.

That said, it is difficult to diagnose drug-induced lung diseases, as the clinical, radiological and histological findings are not specific. The acute lung damage caused by pneumotoxic agents takes the form of alveolitis and lung edema, as they act as antigens or haptens and create immune cascades, resulting in immune-mediated alveolitis. Secondarily, the accumulation of medicationspecific antibodies with medication-specific $T$ cells in the form of antigen/antibody complexes result in lung edema. Acute damage may advance to chronic inflammation in a short period, and may cause fibrotic changes that hinder gas transportation (2).

Acute, sub-acute and chronic phases of drug-induced lung toxicity may be observed. In the acute form, fever, chills, nausea, cough, shortness of breath can be observed; in the sub-acute form, gradually increasing cough, shortness of breath, loss of appetite and weakness can be seen; while in the chronic form, insidious coughing, shortness of breath, loss of weight and fatigue are observed (3-5).

The dose and period of potential drug exposure should be queried in detail. In suspected cases, lung imaging and high-resolution tomography (HRCT) must be performed. The most frequently observed change indicating the stage of the disease is ground-glass or patched opacities (6). Bronchoalveolar lavage (BAL) is the most sensitive method for the detection of alveolitis, and especially in patients with an exposure history and typical findings in HRCT, BAL is not necessary. The role of open lung biopsy in diagnosis is also controversial (7).

Aripiprazole is an atypical anti-psychotic drug that binds to dopaminergic and serotonergic receptors with high affinity. It has fewer side effects (dystonia, Parkinsonism, akathisia, dyskinesia, etc.) than typical anti-psychotics (8). Aripiprazole-related pulmonary complications are few in number, however one such case presented with hypersensitivity pneumonia. It was shown that the same case recovered clinically and radiologically as the result of get- ting away from the factor and following treatment with steroids (9).

In patients presenting with shortness of breath, cough, high fever and diffuse parenchymal involvement in lung imaging, it is important to consider drug toxicity in a differential diagnosis, and to take a detailed history of drug exposure. In our case, considering the sub-acute interstitial pneumonia diagnosis after aripiprazole use, the medication was discontinued and steroid treatment was applied, and clinical and radiological recovery was observed.

The target of treatment is the prevention of inflammatory response and fibrotic tissue accumulation, which requires the avoidance of the triggering factor and treatment with steroids. The response to acute damage can take 24-48 hours, although the treatment response to chronic attacks can take longer. It is recommended to reduce and then stop the steroid treatment over a period of weeks (7).

As regards to the limitations of our study, we carried out no bronchoalveolar lavage or biopsy for diagnosis. The diagnosis was confirmed through the discontinuation of the medication causing lung toxicity. In general, bronchoscopy with transbronchial biopsy will not aid in the establishment of a diagnosis of drug-induced pulmonary toxicity. Bronchoalveolar lavage (BAL) can contribute to the expected clinicopathological pattern of a given druginduced lung disease, such as identifying eosinophils in drug-induced eosinophilic pneumonia. BAL also is helpful in differential diagnoses, primarily by excluding an infective etiology to the pulmonary infiltrates.

We present here a case of drug-induced toxicity, which we submit to literature as a rarely encountered condition.

\section{CONFLICTS OF INTEREST}

None declared.

\section{AUTHOR CONTRIBUTIONS}

Concept - F.S.A., M.E.D., N.K., T.T.; Planning and Design - F.S.A., M.E.D., N.K., T.T.; Supervision - F.S.A., M.E.D., N.K., T.T.; Funding - F.S.A.; Materials - F.S.A.; Data Collection and/or Processing - T.T.; Analysis and/or Interpretation - M.E.D., F.K.; Literature Review - F.S.A.; Writing - F.S.A.; Critical Review - T.T.

\section{YAZAR KATKILARI}

Fikir - F.S.A., M.E.D., N.K., T.T.; Tasarım ve Dizayn F.S.A., M.E.D., N.K., T.T.; Denetleme - F.S.A., M.E.D., N.K., T.T.; Kaynaklar - F.S.A.; Malzemeler - F.S.A.; Veri Toplama ve/veya İşleme - T.T.; Analiz ve/veya Yorum - 
M.E.D., F.K.; Literatür Taraması - F.S.A.; Yazıyı Yazan F.S.A.; Eleştirel İnceleme - T.T.

\section{REFERENCES}

1. Camus P, Rosenow E. Latrogenic lung disease. Clin Chest Med 2004; 25:xiii-xix. [CrossRef]

2. Nemery B, Bast A, Behr J, Brom PJ, Bourke SJ, Camus $\mathrm{PH}$, et al. Interstitial lung disease induced by exogenous agents: factors governing susceptibility. Eur Respir J 2001; $18: 30 s-42 s$.

3. Lynch DA, Rose CS, Way D, King Jr TE. Hypersensitivity pneumonitis: sensitivity of high-resolution CT in a population-based study. AJR Am J Roentgenol 1992; 159:469-72. [CrossRef]

4. Schlveter DP. Response of the lung to inhaled antigens. Am J Med 1974; 57:476-92. [CrossRef]

5. Sansores R, Salas J, Chapela R, Barquin N, Selman M. Clubbing in hypersensitivity pneumonitis: its prevalence and possible prognostic role. Arch Intern Med 1990; 150:1849-51. [CrossRef]
6. Hendrick D, Faux JA, Marshall R. Budgerigar-fancier's lung: the commonest variety of allergic alveolitis in Britain. Br Med J 1978; 2:81-4. [CrossRef]

7. Vasakova M, Morell F, Walsh S, Leslie K, Raghu G. Hypersensitivity pneumonitis: perspectives in diagnosis and management. Am J Respir Crit Care Med 2017; 196:680-9. [CrossRef]

8. Bachu K, Godkar D, Gasparyan A, Sircar P, Yakoby M, Niranjan S. Aripiprazole-induced syndrome of inappropriate antidiuretic hormone secretion (SIADH). Am J Ther 2006; 13:370-2. [CrossRef]

9. Gunasekaran K, Murthi S, Jennings J, Lone N. Aripiprazole-induced hypersensitivity pneumonitis. BMJ Case Rep 2017; 2017:bcr-2017-219929. [CrossRef] 